\title{
The Determinants Of Islamic Retail Banking Adoption In Malaysia
}

\author{
Seethaletchumy Thambiah, Multimedia University, Malaysia \\ Shanti Ramanathan, Multimedia University, Malaysia \\ Mohammad Nurul Huda Mazumder, Multimedia University, Malaysia
}

\begin{abstract}
This study aims to examine the factors affecting the adoption of Islamic retail banking (IRB) products and services among the banking customers of Malaysia. The market share of Islamic retail banking remains low despite being in operation for the past 28 years. Therefore, an empirical analysis was conducted to study the usage of Islamic retail banking products and services between the urban and rural banking customers of Malaysia. Comparisons were also made on the usage of Islamic deposits and financing schemes between the Muslim and nonMuslim customers. The findings of the study revealed, relative advantage, promotional efforts, complexity, compatibility and awareness on attributes of Islamic retail banking as the significant determinants of the usage of Islamic retail banking products and services. Thus, the findings of this study serves as a valuable guideline to the banking sector and policy makers to devise appropriate marketing strategies to promote Islamic retail banking products and services aggressively among the banking customers of Malaysia.
\end{abstract}

Keywords: Islamic Retail Banking; Adoption; Consumer; Malaysia

\section{INTRODUCTION}

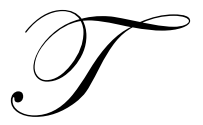

he term "Islamic Banking" is defined as the conduct of banking operations in consonance with Islamic teachings (Mirakhor, 2000; Haque, et al., 2007). The main principles of Islamic banking activities thus, comprise of prohibition of interest (riba) in all forms of transactions undertaking business and trade activities, based on, fair and legitimate profit. Unlike conventional banking system, the Islamic banking system prohibits usury (riba), the collection and payment of interest. Instead, it promotes profit and loss sharing principles in all forms of banking transactions. Other than riba the Islamic banking system also prohibits monopoly. However promotes giving zakat (alms tax) and cooperation for the benefit of society, and development of all halal aspects of business, that are not prohibited by Islam (Haron, 1997; Mirakhor, 2000). Thus, it is realized that the emergence of Islamic financial system has created a new dimension to the current economic models (Aziz, 2005; Fazlan and Mohammad, 2007).

Over the past four decades, Islamic banking has emerged as one of the fastest growing industry, at an estimated growth rate of 15-20 percent per annum (Haque et al., 2007; Aziz, 2010). It has spread to all corners of globe and received wide acceptance by both Muslims and non-Muslims (Aziz, 2006). The Malaysian government too has given great emphasis to develop a well functioning and efficient Islamic banking system in Malaysia. Thus, the vision of Malaysian government is to develop a progressive and robust Islamic banking industry, rooted in the Islamic core values and principles that best serve the needs of the nation's economy. Today, Malaysia has succeeded in implementing a dual banking system and has emerged as the first nation to have a full-fledged Islamic banking system, operating in parallel, with the conventional banking system. The Malaysian Islamic banking system currently comprises of eleven (11) local Islamic banks and six (6) foreign Islamic banks all together (Bank Negara Malaysia, 2010).

Moreover, it is the aspiration of the Malaysian government to have a strong Islamic banking industry capturing 20 percent of the market share of Islamic assets, financing and deposits by 2010 (Aziz, 2007). Although 
the 20 percent of market share has generally been achieved, the growth seemed to be slow and insignificant in comparison to conventional assets, financing and deposits, which are relatively higher. It was critiqued by previous scholars that although there are continuous growth opportunities for Islamic banking in this country, there is a need to develop products and services that are in line with the changing needs and demands of customers to remain competitive in the business (Sadiq and Shanmugam, 2002 ; Haron et al., 2005). A feature of the banking industry across the globe has been that it is increasingly becoming turbulent and competitive (Sadiq and Shanmugham, 2003). The process of globalization and liberalization together with digitalization has fueled the intensity of business competition today. Thus, Islamic banking in Malaysia, as one of the most important components in the service industry is faced with stiff competition, not only with the long established conventional banking system and the international players, but also within themselves.

As competition intensifies, Islamic banking should no longer be regarded as a banking service striving to fulfill only the religious obligations of the Muslim community, but more significantly as an innovation in the banking industry, that ought to be, as competitive as conventional banking. This necessitates Islamic financial institutions to understand the real needs and demands of their customers towards Islamic banking products and services. This necessitates the present study, which aims to examine the factors affecting the adoption of Islamic retail banking products and services in Malaysia.

\section{RESEARCH OBJECTIVES}

Therefore, the main objective of the present study is to understand the nature of consumer usage of Islamic banking, in particular retail banking, in Malaysia and the specific objectives are as follows:

- $\quad$ To examine the usage of Islamic retail banking between urban and rural banking customers of Malaysia.

- To analyze the usage of Islamic retail banking among the Muslim and non-Muslim banking customers.

- $\quad$ To determine the factors which determine the usage of Islamic retail banking in Malaysia.

The following section describes briefly on the research methodology. Subsequently, the results and implications of the findings are discussed. The final section ends with the limitation of the study and a concluding remark.

\section{RESEARCH METHODOLOGY}

To determine the adoption of Islamic retail banking products and services, a survey was conducted among the banking customers of Malaysia, during October to December 2010. A survey instrument was designed to collect data. The instrument itself was a questionnaire designed previously (Yusof, 1999), consisting 32-questions that measures eight key constructs of the study. Initially the respondents were asked to indicate their current usage of Islamic retail banking deposit and financing schemes. The following section consist questions related to consumers' perception on IRB products and services. Responses to the question on the variables were entered on a five-point Likert-type scale as follows: $1=$ Strongly Disagree, $2=$ Disagree, $3=$ Neither Agree or Disagree, $4=$ Agree and $5=$ Strongly Agree. The final section consists of the demographic profile of the respondents that include; gender, age, ethnicity, and religion, level of education, monthly income, and occupation.

Individual customers of banking sector from the urban and rural regions of Malaysia participated in this study. The urban regions are represented by the main cities in Malaysia comprising, Kuala Lumpur, Seremban, Johore Bahru, Kuantan, Ipoh, GeorgeTown, Kota Bahru and Kuala Terengganu. Correspondingly the rural regions are represented by, Sekinchan, Bahau, Labis, Chaah, Raub, Sungkai, Pasir Mas and Kuala Berang. Therefore, the urban and rural locations of the study overall cover the northern, central, southern and eastern regions of Malaysia. The composition of the respondents of the present study is made up of both Muslim and non-Muslims. comprised of both Muslim and non-Muslims. The sample for urban regions was drawn from bank customers at three leading banks of Malaysia and, as for the rural regions; it was drawn from the mosques and households. The survey instrument was personally administered, and administered through the medium of Internet. Hardcopies of questionnaires were distributed using convenient sampling while online questionnaires were sent out randomly to friends and colleagues in the mailing list. A total of 281 useable responses from the urban region and 256 from the rural region were obtained. 


\section{DATA ANALYSIS}

\subsection{Usage of Islamic retail banking products and services between the urban and rural customers}

To make a comparison of the usage of IRB products and services between the urban and rural banking customers, a cross-tabulation analysis was conducted. The underlying reason for such an analysis is to examine whether regional barriers affect the adoption of Islamic retail banking usage in Malaysia. The result revealed, higher percentage of respondents who operate IRB products and services come from urban regions of Malaysia, in comparison to the rural customers as depicted in Table 1. In total approximately 40.8 percent of banking customers seemed to use IRB products and services such as Islamic deposits and financing schemes. In that, nearly 25 percent were urbanites and 15.8 percent were rural customers. The percentage of customers who do not use any Islamic retail banking products and services, make up nearly $59.2 \%$. In that, $27.4 \%$ are urbanites and the remaining $31.8 \%$ are rural customers. It is surprising to note that the majority of the banking customers in Malaysia still have not adopted Islamic banking, despite the fact that it has been operating for the past three decades now.

Table 1: Cross Tabulation between Region and Usage of Islamic Retail Banking Schemes

\begin{tabular}{|l|c|c|}
\hline \multicolumn{1}{|c|}{ Region } & Yes (\%) & Usage of Islamic Retail Banking \\
\hline & 25.0 & 27.4 \\
\hline Urban & 15.8 & 31.8 \\
\hline Rural & 40.8 & 59.2 \\
\hline Total & Value & Asymp. Sig \\
\hline Chi-Square Test & 0.147 & 0.001 \\
\hline Phi & 0.147 & 0.001 \\
\hline Cramer's V & 11.636 & 0.001 \\
\hline Pearson $\chi^{2}$ & & \\
\hline
\end{tabular}

Moreover, the Chi-Square statistics between region and usage of Islamic retail banking revealed Pearson $\chi^{2}$ value of $(1,537)=11.636 ; p=0.001(<0.05$ significance level $)$. This confirms that there is statistical significance between region and the usage of Islamic retail banking. Subsequent findings from the symmetric measure of Cramer's V, $0.147(\mathrm{p}=0.001)$ further emphasized that there is a significant association between region and usage of Islamic retail banking schemes.

\subsection{Usage of Islamic retail banking between Muslim and non-Muslim banking customers.}

An independent samples t-test was conducted to identify if there is a significance difference in usage of IRB products and services between the Muslim and non-Muslim banking customers of Malaysia. The independent samples t-test is consider appropriate in order to examine if there is a significant difference in the means for two groups in the variables of interest, with the assumptions that, independence of groups and homogeneity of variance are met (Sekaran, 2003; Coakes, 2009).

The Table 2 below shows the findings of the $t$-test analysis. Prior to that the "Levene's test" for equality of variances was considered. Given that, the equality of variances for the usage of IRB, the Levene's test shows an insignificant result, with p-value $0.159(>0.05)$, thus equal variance estimates were interpreted. The difference in the means of 4.188 and 3.761 with standard deviations of 3.849 and 3.213 for the Muslims and non-Muslim customers shows significant difference, where $t(535)=4.354, p=0.000(<0.05)$. Moreover, there seemed to be a significant difference between the Muslim and non-Muslims customers, concerning their usage of Islamic retail banking products and services. Obviously, the majority of users, approximately 73 percent were Muslims and only 27 percent were non-Muslims.

Table 2: Results of Independent Samples $t$-test Analysis on IRB usage between Muslim and non-Muslim Customers

\begin{tabular}{|l|c|c|c|c|c|c|}
\hline \multirow{2}{*}{ Religion } & \multicolumn{5}{|c|}{ Usage of Islamic Retail Banking } \\
\cline { 3 - 6 } & Mean & SD & Levene's p-value & t-value & \multirow{2}{*}{ Sig. } \\
\hline Muslims & 281 & 4.1881 & 3.84995 & \multirow{2}{*}{0.171} & \multirow{2}{*}{4.354} & \multirow{2}{*}{0.000} \\
\hline Non-Muslims & 256 & 3.761 & 3.21382 & & & \\
\hline
\end{tabular}




\subsection{Factors that determine the current usage of Islamic retail banking}

This section presents the factors that predict the usage of IRB. Multiple linear regression (MLR) was used to conduct the analysis. As it is one of the widely used multivariate techniques in research to determine whether the independent variables of the study explain a significant variation (relationship) in the dependent variable, with the condition that both variables must be metric (Malhotra, 2007; Hair et al., 2010). Thus, for the purpose of this study MLR was run on eight independent variables: Awareness of IRB Attributes, Relative Advantage, Compatibility, Complexity, Observability, Uncertainty, Promotional efforts and Perceived Information Quality against Usage of $I R B$, which is the dependent variable.

Table 3 below, illustrates the results of Multiple Linear Regression for the usage of IRB. Initially the eight independent variables produced an adjusted $R^{2}$ of 0.329 and $\mathrm{F}(8,204)=48.837, p=0.000$, for the prediction of Islamic retail banking usage. The predictor with the lowest non-significant regression coefficient (Observability, $B=$ $.001, t(202)=0.017, p=0.986)$ was removed and another regression analysis conducted which had an adjusted $R^{2}$ of 0.334 . The next predictor with the lowest non-significant regression coefficient (Uncertainty, $B=-0.008, t$ (202) $=-0.110, p=.0 .913$ ) was removed. Subsequently, (Information Quality, $B=0.036, t(202)=0.608, p=0.544$ ) was also eliminated. Thus, the final regression analysis conducted revealed an $R$ of $0.587, R^{2}=0.345$ and an adjusted $R^{2}$ of $0.339(F(8,204)=60.739, p=0.000)$, with five significant predictors of IRB Usage: Awareness on Attributes of IRB, Relative Advantage, Compatibility, Complexity and Promotional efforts at $\mathrm{p}<0.05$ level. In addition, the five independent variables together explain approximately $33.9 \%$, of the variance concerning the usage of IRB, which is relatively significant, as indicated by the F-value of 60.739 in Table 3. Thus, based on the foregoing result the following regression equation is derived:

$\mathrm{Y}=2.101+.150 \mathrm{X} 1+.112 \mathrm{X} 2+(-.086) \mathrm{X} 3+.085 \mathrm{X} 4+.050 \mathrm{X} 5+.226$

WhereY: Usage of IRB (Dependent variable)

X1: Relative Advantage

X2: Promotional efforts

X3: Complexity

X4: Compatibility

X5: Awareness on Attributes of IRB

The regression equation denotes that, a 1-unit increase in Relative Advantage, the usage of IRB products and services will increase by 0.150 units, given that other predictors remain constant. Likewise, an increase of Promotional efforts by 1- unit will increase the IRB usage by 0.112 units, provided other variables remain unchanged. Subsequently, a 1-unit increase in Complexity will cause a decrease in the usage of IRB by 0.086 units, and a 1- unit increase in Compatibility will cause an increase in the usage of IRB by 0.085 units. Finally, a 1-unit increase in consumer awareness on IRB attributes will cause an increase in the usage of IRB by 0.05 units, with other independent variables held constant.

Table 3: Model Summary of the Factors Determining IRB Usage

\begin{tabular}{|c|c|c|c|c|c|}
\hline $\mathbf{R}$ & R Square & $\begin{array}{c}\text { Adjusted R } \\
\text { Square }\end{array}$ & $\begin{array}{c}\text { Std. Error of the } \\
\text { Estimate }\end{array}$ & F & $\begin{array}{c}\text { Sig } \\
\text { (p-value) }\end{array}$ \\
\hline 0.587 & 0.345 & 0.339 & 0.10107 & 60.739 & 0.000 \\
\hline
\end{tabular}

Therefore it can be evident, approximately $33.9 \%$ of the variance of the usage of IRB in Malaysia is explained by Relative Advantage, Promotional efforts, Complexity, Compatibility and Awareness on Attributes of IRB. However among all, Relative Advantage (Beta $=0.214)$ emerged as the best predictor, followed by Compatibility $($ Beta $=0.177)$, Promotional efforts $($ Beta $=.175)$, Complexity $($ Beta $=-.118)$ and finally Awareness on IRB Attributes (Beta $=0.050)$ as shown in Table 4. 
Table 4: Coefficient Results for Influence of Independent variables on Usage of IRB

\begin{tabular}{|l|c|c|c|c|c|c|c|}
\hline \multirow{2}{*}{ Variables } & \multicolumn{2}{c}{$\begin{array}{c}\text { UnStandardized } \\
\text { Coefficients }\end{array}$} & $\begin{array}{c}\text { Standardized } \\
\text { Coefficients }\end{array}$ & \multirow{2}{*}{$\boldsymbol{t}$} & \multirow{2}{*}{ Sig } & \multicolumn{2}{c|}{$\begin{array}{c}\text { Collinearity } \\
\text { Statistics }\end{array}$} \\
\cline { 2 - 7 } & B & Std Error & Beta & & & Tolerance & VIF \\
\hline Constant & 2.101 & .226 & & 9.298 & .000 & & \\
\hline Awareness on IRB Attributes & .050 & .044 & .076 & 1.128 & .041 & .734 & 1.363 \\
\hline Relative Advantage & .150 & .054 & .214 & 2.778 & .006 & .562 & 1.780 \\
\hline Compatibility & .085 & .035 & .177 & 2.475 & .014 & .647 & 1.546 \\
\hline Complexity & -.086 & .025 & -.118 & -2.382 & .001 & .802 & 1.246 \\
\hline Observability & .001 & .035 & .001 & .017 & .986 & .609 & 1.642 \\
\hline Uncertainty & -.003 & .028 & -.008 & -.110 & .913 & .661 & 1.512 \\
\hline Promotional efforts & .112 & .038 & .175 & 2.909 & .004 & .915 & 1.093 \\
\hline Perceived Information Quality & .023 & .037 & .037 & .608 & .544 & .925 & 1.082 \\
\hline
\end{tabular}

\section{CONCLUDING REMARKS}

This study revealed that there is a significant difference in usage of IRB products and services between the urban and rural customers. Obviously, the usage is more apparent among the urban customers probably because of their banking exposure and easy accessibility. This is due to the reason that most of the financial institutions in Malaysia are located in the urban regions. Thus, the level of baking exposure and banking practices is higher among the urbanites in comparison to the rural customers. Therefore, it is vital that the Malaysian financial institutions should bridge this barrier by implementing mobile branches and mini-kiosk to reach out to the rural customers. As to accelerate the usage of IRB products and services among the non-Muslim customers, the present promotional strategies ought to be changed to the ones that expose and educate customers on the benefits of IRB schemes. The financial institutions should emphasis more on personal selling and interactive marketing techniques. Whereby, the sales personnel are able to communicate the benefits of IRB products and services to the potential customers, convincing them to use it.

As for the factors affecting the usage of IRB products and services, five (5) factors, namely Relative Advantage, Compatibility, Promotional Efforts, Complexity and Consumer Awareness on IRB attributes, seemed to have significant relationship with usage of IRB. Given that, financial and economical superiority of IRB products and services seemed to be the main factor that attracts the current usage. Second is the perceived compatibility of IRB products and services, which seemed to influence the current usage of IRB, since the current users may find it as congruent to their religious beliefs, lifestyle and banking habits. Subsequently, the promotional efforts by the financial institutions have actually influenced the current usage of IRB. The fourth factor, which actually affects the current usage of IRB, is perceived complexity among the users. This indicates that the current users still perceive IRB as complex to a certain extent. Finally, customers' awareness on IRB attributes also seemed to contribute towards usage of IRB products and services.

\section{AUTHOR INFORMATION}

Seethaletchumy Thambiah is a lecturer and a $\mathrm{PhD}$ fellow with Faculty of Management, Multimedia University, Malaysia. She was awarded Master of Business Administration from University of Ballarat, Australia. She is the reviewer of International Business Information Management Association (IBIMA) conferences, and her research interests include Islamic Banking, Financial Services, Consumer Behavior and Customer Relationship Management. E-mail: seethaletchumy@mmu.edu.my. Corresponding author.

Dr. Santhi Ramanathan received her PhD in Development Economics from University of Malaya (UM), Malaysia. Her other academic qualifications include Master degree in Economics and Bachelor's degree in Analytical Economics from University of Malaya (UM), Malaysia. Dr Santhi is currently an academician attached to Multimedia University (MMU), Malaysia. She teaches and conducts research in the area of Economics and Management. E-mail: santhi@mmu.edu.my. 
Dr. Mohammad Nurul Huda Mazumder is a senior lecturer and subject coordinator for under graduate programs at Faculty of Management, Multimedia University, Cyberjaya Campus, Malaysia. An associate editor and reviewer of couple of international journals and conferences, his research interests include Tourism Economics, Tourism, Micro Finance, Poverty Eradication and Sustainable Development, Environmental Economics, Islamic Economics, Financial Markets and Statistical Methods. E-mail: mohammad@mmu.edu.my.

\section{REFERENCES}

1. Asyraf, W, D \& Nurdianawati, A (2007) 'Why do Malaysian Customers patronize Islamic Banks', International Journal of Bank Marketing, 25:3, 142-160.

2. Aziz, Z.A., (2005) Building a progressive Islamic Banking sector: Charting the Way Forward, 10-Year Master Plan for Islamic Financial Services Industry, Bank Negara Malaysia, Kuala Lumpur.

3. Aziz, Z.A., (2006) Islamic Banking and Finance Progress and Prospects, Collected Speeches 2000-2006, Bank Negara Malaysia, Kuala Lumpur.

4. Aziz, Z.A., (2007) Governor of Central Bank of Malaysia: Keynote address at INCEIF, Inaugural Intellectual Discourse, 23 February, Kuala Lumpur.

5. Aziz, Z.A., (2010) Governor of Central Bank of Malaysia: Keynote address at the Financial Industry Conference, 3 November, Kuala Lumpur.

6. Bank Negara Malaysia (BNM), (2010), Annual Report, Kuala Lumpur.

7. Coakes, S.J., Steed, L. and Ong, C., (2009), Analysis without Anguish: SPSS version 16.0 for Windows, John Wiley and Sons, Australia, Ltd.

8. Fazlan, S. and Mohammad, A., (2007) 'The efficiency of Islamic Banks: Empirical Evidence from the MENA and Asian Countries Islamic Banking Sectors', paper presented at the Fifth International Islamic Finance Conference, $3-4^{\text {th }}$ September, Kuala Lumpur.

9. Hair, J.F., Black,W.C., Babin, B.J, and Anderson, R.E, (2010), Multivariate Data Analysis- A Global Perspective- $7^{\text {th }}$ Edition, Pearson Prentice Hall, Inc, USA.

10. Haron, S., (1997) Islamic Banking Rules and Regulations, Pelanduk Publications (M) Sdn Bhd, Kuala Lumpur.

11. Haron, S., and Nursofiza, W.A, (2005), "Marketing Strategy of Islamic Banks: A Lesson from Malaysia", International Seminar on Enhancing Competitive Advantage on Islamic Financial Institutions.

12. Haque, A., Jamil.O \& Ahmad .Z (2007) 'Islamic Banking: Customer perception and its prospect on bank product selection towards Malaysian customer perspectives', paper presented at the Fifth International Islamic Finance Conference, $3-4^{\text {th }}$ September, Kuala Lumpur.

13. Iqbal, $\mathrm{Z}$ and Mirakhor, A., (2007) An Introduction to Islamic Finance: Theory and Practice, John Wiley and Sons Ltd, Chichester.

14. Hassan, K., and M.K.Lewis, (2007), Handbook of Islamic Banking, Edward Elgar Publishing Limited, UK.

15. Malhotra, N.K., (2007), Marketing Research: An Applied Orientation, $5^{\text {th }}$ ed., Pearson Prentice Hall, Pearson Education, Inc., New Jersey.

16. Mirakhor, A., (2000) 'General Characteristics of an Islamic Economic System', Anthology of Islamic Banking, Institute of Islamic Banking and Insurance, London, p.11-31.

17. Sadiq, S., and Shanmugham, B., (2002) 'E-banking and customer preferences in Malaysia: an Empirical investigation', International Journal of Information Sciences (Elsevier), 15:2, 207-217.

18. Sekaran, U. (2006), Research Methods for Business: A Skill Building Approach, $4^{\text {th }}$ ed., John Wiley and Sons, Inc., New York, NY.

19. Yusof, M.Y.R, (1999) 'Islamic Banking: Adoption of a Service Innovation', unpublished MSc. thesis, NTU, Singapore. 